\title{
Food Composition Data: Edible Plants in Pantanal
}

\author{
Ieda Maria Bortolotto, Rita de Cássia Avellaneda Guimarães, \\ Raquel Pires Campos, Mariana Rodrigues da Silva Lopes, \\ Laleska Pâmela Rodrigues da Silva, Rosa Helena Silva, \\ Geraldo Alves Damasceno-Junior, Arnildo Pott, and Priscila Aiko Hiane
}

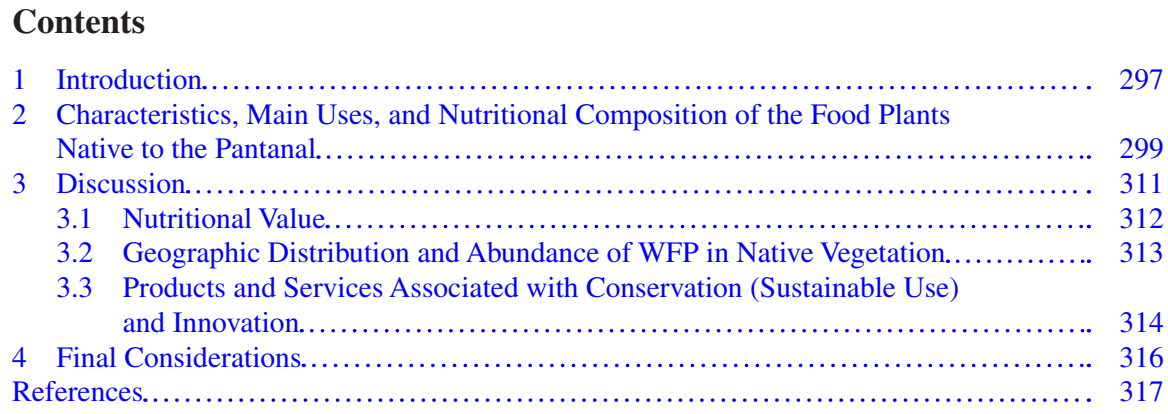

\section{Introduction}

The Pantanal is one of the largest wetlands on Earth, the most part in Brazil, besides Bolivia and Paraguay (Adámoli 1982). The vegetation is represented by a mosaic of physiognomies that occur in floodable and flood-free areas, with influence from

\footnotetext{
I. M. Bortolotto $(\bowtie) \cdot$ R. H. Silva · G. A. Damasceno-Junior · A. Pott Programa de Pós-Graduação em Biologia Vegetal, Instituto de Biociências, Universidade Federal de Mato Grosso do Sul, Campo Grande, MS, Brazil

R. de Cássia Avellaneda Guimarães · M. R. da Silva Lopes · L. P. R. da Silva Programa de Pós-Graduação em Saúde e Desenvolvimento na Região Centro-Oeste, Faculdade de Medicina, Universidade Federal de Mato Grosso do Sul, Campo Grande, MS, Brazil e-mail: rita.guimaraes@ufms.br

R. P. Campos · P. A. Hiane

Faculdade de Ciências Farmacêuticas, Alimentos e Nutrição, Universidade Federal de Mato Grosso do Sul, Campo Grande, MS, Brazil

e-mail: raquel.campos@ufms.br; priscila.hiane@ufms.br
} 
Cerrado, Chaco, and Amazon Forest (Prance and Schaller 1982), with over 2500 catalogued species of angiosperms (Pott and Pott (in press)). Hundreds of native species have a potential for alimentary use for both human and animals (Pott and Pott 1986, 1994; Pott et al. 2004; Bortolotto et al. 2018). Among them, circa 70 species were recorded as part of the diet and culture of the human populations living in indigenous and traditional communities in the western edge of the Pantanal (Bortolotto et al. 2015; Bortolotto et al. 2019). Among them, there are some species associated with rich traditional knowledge on their use in the diet, relevant in the past, were abandoned, or have low use value now.

Nuts and pulps of fruits, leaves, rhizomes, and other parts of food plants native to the Pantanal have relevant nutritional value with high levels of fibers, sugars, proteins, minerals, fatty acids, vitamins, and carotenoids (Hiane et al. 2006; Ramos et al. 2008; Prates et al. 2015; Arakaki et al. 2020). Besides, they have bioactive compounds with antioxidant action, and their inclusion in the diet protects the organism from several chronic diseases associated with oxidative stress (Pereira and Cardoso 2012).

The consumption of wild foods, free of agrochemicals, is also associated with sustainable actions, being beneficial for health and the environment. The inclusion of regional foods and native fruits in the diet of the population can be an economical and sustainable way of preventing diseases associated with malnutrition and represents an alternative for consumers, constituting a new source of foods, raw materials, new products, and wealth for the country (Marin 2006; Silva et al. 2010).

Several epidemiological studies indicate that the high ingestion of plant products is associated with a reduced risk of a variety of chronic diseases such as atherosclerosis and cancer, effects that have been particularly attributed to the compounds in antioxidant activity: vitamins $\mathrm{C}$ and $\mathrm{E}$, phenolic compounds, especially flavonoids, and carotenoids (Silva et al. 2010). The antioxidants ingested in the human diet, such as vitamin $\mathrm{C}$ and phenolic compounds, can prevent carcinogenesis for scavenging the free radicals and impeding the linkage of the carcinogens to DNA (Valko et al. 2006).

Some native food species have edible parts with peculiar organoleptic characteristics, which make them distinct and can be included in new compounds potentially toxic to human beings (Pinela et al. 2017). Thus, the native food plants with traditional use deserve a distinct value since they offer the necessary security to indicate their alimentary use proven over centuries by the people consuming them frequently (Pardo de Santayana et al. 2012). Many species with high cultural value have an essential role in the human diet for being functional foods, capable of providing benefits to health, besides nutritional value, and being strategic for food and nutrition security and food sovereignty (Wittman 2012). The native food plants can also be useful as supplementary, seasonal, or subsistence sources in many cultural groups and play an essential role in fighting food shortage (Lulekal et al. 2011). Additionally, the fruits of native species from Brazil have nutraceutical properties for their characteristics being comparable to commercial drugs (dos Santos et al. 2017).

This chapter compiles nutritional information about 11 traditional native food species of the Pantanal abundant in natural plant physiognomies that have great 
potential for sustainable use associated with food and nutrition security and food sovereignty. The species were selected among those with the highest use value by two ethnobotanical studies (Bortolotto et al. 2015; Bortolotto et al. 2019) developed in the municipalities of Corumbá and Porto Murtinho, in the State of Mato Grosso do Sul, in the extreme west of the Brazilian Pantanal, besides one traditionally used in the past in this region. For each species, we searched published information on their nutritional composition, traditional uses, distribution, and phenological and abundance data around the communities.

This region has an altitudinal gradient varying between $80 \mathrm{~m}$ on the plain and $1064 \mathrm{~m}$ in areas of the Urucum-Amolar hills (Borges et al. 1997). Besides aquatic and wetland plants present in water bodies, riparian forests, and floodplain, there is high species richness in the vegetation of Cerrado and in seasonal deciduous and semideciduous forest (Prance and Schaller 1982; Damasceno-Junior et al. 2017) in more elevated areas. The municipality of Porto Murtinho, in the southernmost portion of the Pantanal, contains an area with Chaco vegetation, distributed in Argentina, Paraguay, Bolivia, and Brazil, in Mato Grosso do Sul (Prado et al. 1992). Porto Murtinho has 15,372 inhabitants, being 5313 habitants in the rural and 10,059 in the urban zone; the municipality of Corumbá has a population of 103,772 inhabitants, being 93,452 in the urban zone and 10,251 in the rural area (IBGE 2010). The study of Porto Murtinho includes persons who live in rural and urban area, while the study of Corumbá includes only persons of an indigenous community and three traditional in the rural area.

\section{Characteristics, Main Uses, and Nutritional Composition of the Food Plants Native to the Pantanal}

The 11 wild food species traditionally utilized by the human populations of the urban and rural area along the Paraguay River in the Pantanal (Brazil) selected for this work are presented in Table 1. We included three species of Arecaceae, two Fabaceae, and one representative of Rubiaceae, Sapotaceae, Poaceae, Lamiaceae, Malpighiaceae, and Myrtaceae. Except for Byrsonima cydoniifolia A. Juss., mentioned only for the municipality of Corumbá, Oryza latifolia Desv. (that was in disuse), and Inga laurina (Sw.) Willd only for Porto Murtinho, the other species were cited for both municipalities.

\section{Arecaceae}

\section{Acrocomia aculeata (Jacq.) Lodd ex. Mart.}

Acrocomia aculeata is a palm locally known as bocaiuva or macauba (Table 1). It has a wide distribution in South and Central America, except Amazonia (Table 1). The drupaceous fruit is rounded with a diameter of $2.5-5.0 \mathrm{~cm}$. The kernel is resistant and dark (black). The pulp color varies from yellow to orange (Fig. 1a, b) with a slightly sweetish taste. In the Pantanal, A. aculeata has several traditional uses in 
Table 1 List of the 11 species of food plants of the Pantanal, Mato Grosso do Sul, Brazil, with botanical family, species, local name, edible part used and mode of consumption, fructification season, and occurrences

\begin{tabular}{|c|c|c|c|c|}
\hline Family/species & Local name & $\begin{array}{l}\text { Edible parts and } \\
\text { traditional } \\
\text { consumption mode } \\
\text { in Pantanal }\end{array}$ & $\begin{array}{l}\text { Fruiting } \\
\text { season } \\
\text { (maturation) }\end{array}$ & Occurrences \\
\hline $\begin{array}{l}\text { Arecaceae } \\
\text { Acrocomia } \\
\text { aculeata } \\
\text { (Jacq.) Lodd. }\end{array}$ & $\begin{array}{l}\text { Bocaiuva, } \\
\text { macauba }\end{array}$ & $\begin{array}{l}\text { Palm heart roasted } \\
\text { or baked; fruit } \\
\text { (pulp and } \\
\text { almonds), ripe pulp } \\
\text { (mesocarp), used } \\
\text { to make bocaiuva } \\
\text { flour, drink (liquor, } \\
\text { fresh or fermented } \\
\text { juice), almonds } \\
\text { eaten raw or } \\
\text { toasted; used to } \\
\text { make oil }(1,2,3)\end{array}$ & $\begin{array}{l}\text { September to } \\
\text { December } \\
(4)\end{array}$ & $\begin{array}{l}\text { South and Central } \\
\text { America, from Argentina } \\
\text { to México (5); Brazil, } \\
\text { except in the Amazon (6); } \\
\text { Pantanal: An, De, Sd, Ce, } \\
\text { Rf (1); Ms }\end{array}$ \\
\hline $\begin{array}{l}\text { Attalea } \\
\text { phalerata } \\
\text { Mart. ex } \\
\text { Spreng. }\end{array}$ & Acuri, bacuri & $\begin{array}{l}\text { Pulp unripe or ripe } \\
\text { fruits eaten cooked, } \\
\text { palm heart baked } \\
\text { (1); ripe pulp } \\
\text { (mesocarp) used to } \\
\text { make acuri flour } \\
\text { (3); almonds eaten } \\
\text { raw; used to make } \\
\text { oil }(1,3)\end{array}$ & $\begin{array}{l}\text { April to } \\
\text { October (2) }\end{array}$ & $\begin{array}{l}\text { South America, from } \\
\text { Brazil to Peru (5); Brazil, } \\
\text { Cerrado and Pantanal (6); } \\
\text { Pantanal, An, De, Sd, Ce, } \\
\operatorname{Rf}(1) ; \text { Ms (2) }\end{array}$ \\
\hline $\begin{array}{l}\text { Copernicia } \\
\text { alba Morong }\end{array}$ & Carandá & $\begin{array}{l}\text { Heart palm and } \\
\text { ripe fruit (in } \\
\text { natura) }\end{array}$ & $\begin{array}{l}\text { February to } \\
\text { May (2) }\end{array}$ & $\begin{array}{l}\text { South America, Brazil, } \\
\text { Bolivia, Paraguai and } \\
\text { Argentina (5); Brazil, } \\
\text { Pantanal, in Rf; Ms }\end{array}$ \\
\hline $\begin{array}{l}\text { Fabaceae } \\
\text { Inga laurina } \\
\text { (Sw.) Will. }\end{array}$ & Ingá & $\begin{array}{l}\text { Sarcotest seed } \\
\text { consumed fresh (7) }\end{array}$ & $\begin{array}{l}\text { November to } \\
\text { March (8) }\end{array}$ & $\begin{array}{l}\text { South and Central } \\
\text { America, from Mexico to } \\
\text { Paraguay and Argentina } \\
\text { (5); Brazil, Amazônia, } \\
\text { Caatinga, and Cerrado (6); } \\
\text { Pantanal, Sd, Rf }\end{array}$ \\
\hline $\begin{array}{l}\text { Fabaceae } \\
\text { Prosopis } \\
\text { ruscifolia } \\
\text { Griseb. }\end{array}$ & Algarrobo & $\begin{array}{l}\text { Fruits to make } \\
\text { algarrobo flour, to } \\
\text { prepare breads, } \\
\text { cakes, and an } \\
\text { alcoholic drink } \\
\text { (chicha) (7) }\end{array}$ & $\begin{array}{l}\text { November to } \\
\text { February (9) }\end{array}$ & $\begin{array}{l}\text { South America, Argentina, } \\
\text { Paraguay, Bolivia, and } \\
\text { Brazil (5); Brazil, Pantanal } \\
\text { and Caatinga (6); Pantanal, } \\
\text { De, Ce, Ch (1) }\end{array}$ \\
\hline $\begin{array}{l}\text { Lamiaceae } \\
\text { Vitex cymosa } \\
\text { Bertero ex } \\
\text { Spreng. }\end{array}$ & Tarumã & $\begin{array}{l}\text { Ripe fruits (pulp) } \\
\text { eaten fresh (1), } \\
\text { used to make jams } \\
\text { (3) }\end{array}$ & $\begin{array}{l}\text { November to } \\
\text { February (2) }\end{array}$ & $\begin{array}{l}\text { South and Central America } \\
\text { (5); Brazil, Amazônia, } \\
\text { Caatinga, Cerrado, Mata } \\
\text { Atlântica and Pantanal (6); } \\
\text { Pantanal, Rf, Sd (1) }\end{array}$ \\
\hline
\end{tabular}


Table 1 (continued)

\begin{tabular}{|c|c|c|c|c|}
\hline Family/species & Local name & $\begin{array}{l}\text { Edible parts and } \\
\text { traditional } \\
\text { consumption mode } \\
\text { in Pantanal }\end{array}$ & $\begin{array}{l}\text { Fruiting } \\
\text { season } \\
\text { (maturation) }\end{array}$ & Occurrences \\
\hline $\begin{array}{l}\text { Malpighiaceae } \\
\text { Byrsonima } \\
\text { cydoniifolia } \\
\text { A. Juss. }\end{array}$ & $\begin{array}{l}\text { Canjiquinha, } \\
\text { canjiqueira }\end{array}$ & $\begin{array}{l}\text { Ripe fruits (pulp) } \\
\text { eaten fresh (1), } \\
\text { juice (acid) (3) }\end{array}$ & $\begin{array}{l}\text { September to } \\
\text { March } \\
\text { (3) and April } \\
\text { (com. Pess.) }\end{array}$ & $\begin{array}{l}\text { Bolivia and Brazil (5); } \\
\text { Brazil, Caatinga, } \\
\text { Cerrado and Pantanal (6); } \\
\text { Pantanal, Rf, Fl (1); Ms }\end{array}$ \\
\hline $\begin{array}{l}\text { Myrtaceae } \\
\text { Plinia } \\
\text { cauliflora } \\
\text { (DC.) Kausel }\end{array}$ & Jabuticaba & $\begin{array}{l}\text { Ripe fruits eaten } \\
\text { fresh, like a jam } \\
\text { and vinegar (1), } \\
\text { liquor }\end{array}$ & $\begin{array}{l}\text { October to } \\
\text { December } \\
\text { (2) }\end{array}$ & $\begin{array}{l}\text { South, Central, and North } \\
\text { America, as well as records } \\
\text { in Australia and South } \\
\text { Africa (6); Brazil, Mata } \\
\text { Atlântica (5); Pantanal, De, } \\
\text { An }\end{array}$ \\
\hline $\begin{array}{l}\text { Poaceae } \\
\text { Oryza latifolia } \\
\text { Desv. }\end{array}$ & $\begin{array}{l}\text { Arroz-do- } \\
\text { pantanal, } \\
\text { arroz-do- } \\
\text { campo }\end{array}$ & $\begin{array}{l}\text { Seeds: galinhada } \\
\text { (rice and jerk } \\
\text { chicken) (3) }\end{array}$ & $\begin{array}{l}\text { May to June } \\
\text { (2) }\end{array}$ & $\begin{array}{l}\text { South and Central } \\
\text { America, from Brazil to } \\
\text { México (5); Brazil, } \\
\text { Amazônia, Cerrado, Mata } \\
\text { Atlântica, and Pantanal (6); } \\
\text { Pantanal, Fl (1); Ms }\end{array}$ \\
\hline $\begin{array}{l}\text { Rubiaceae } \\
\text { Genipa } \\
\text { americana L. }\end{array}$ & Jenipapo & $\begin{array}{l}\text { Ripe fruits (pulp) } \\
\text { used to make jams } \\
\text { and liquor (1) and } \\
\text { juice (3) }\end{array}$ & $\begin{array}{l}\text { October to } \\
\text { December } \\
\text { (2) }\end{array}$ & $\begin{array}{l}\text { South and Central } \\
\text { America, from Argentina } \\
\text { to México (5); Brazil } \\
\text { Amazônia, Caatinga, } \\
\text { Cerrado, Mata Atlântica } \\
\text { and Pantanal (6); Pantanal, } \\
\text { An, Rf }\end{array}$ \\
\hline $\begin{array}{l}\text { Sapotaceae } \\
\text { Pouteria } \\
\text { glomerata } \\
\text { (Miq.) Radlk. }\end{array}$ & $\begin{array}{l}\text { Laranjinha- } \\
\text { de-pacu }\end{array}$ & $\begin{array}{l}\text { Ripe fruits (pulp) } \\
\text { eaten fresh (1) }\end{array}$ & $\begin{array}{l}\text { January to } \\
\text { August (2) }\end{array}$ & $\begin{array}{l}\text { South and Central } \\
\text { America, from Brazil to } \\
\text { México (5); Brazil, } \\
\text { Amazônia, Cerrado, and } \\
\text { Mata Atlântica (6); } \\
\text { Pantanal, Rf }\end{array}$ \\
\hline
\end{tabular}

Sources: (1) Bortolotto et al. (2015), (2) Pott and Pott (1994), (3) Damasceno-Junior and Souza (2010), (4) Salis and Mattos (2009), (5) GBIF.org (2018), (6) Flora do Brasil (2020), (7) Bortolotto et al. (2019), (8) Pennington (1997), (9) de Matos Alves (2014)

$\mathrm{De}$ Deciduous forest, $\mathrm{Sd}$ semideciduous forest, $\mathrm{Ce}$ Cerrado, $R f$ riparian forest, $\mathrm{Fl}$ floodplains, $\mathrm{Ch}$ Chaco, An anthropogenic, and $M s$ monodominant stands

the diet, utilizing the pulp, heart of palm, and nut (Table 1). The fruit pulp is used for consumption in natura and in cakes, ice creams, and flour; the nut has several alimentary uses in natura, in preparing coconut sweet and milk mix, and in the production of edible oil (Bortolotto et al. 2017) and jams (da Silva et al. 2017). It has excellent yield (each bunch produces $6.32 \mathrm{~kg}$ of pulp and $1.36 \mathrm{~kg}$ of endosperm (nut) (Sanjinez-Argandoña and Chuba 2011)). In Corumbá, the flour obtained from the dehydrated pulp is commercialized (Dias and Galvani 2017).

The stipe and the roots contain starch (Peña 1976), but their uses were not observed in the Pantanal. The flour obtained from the processed amylaceous fibers 


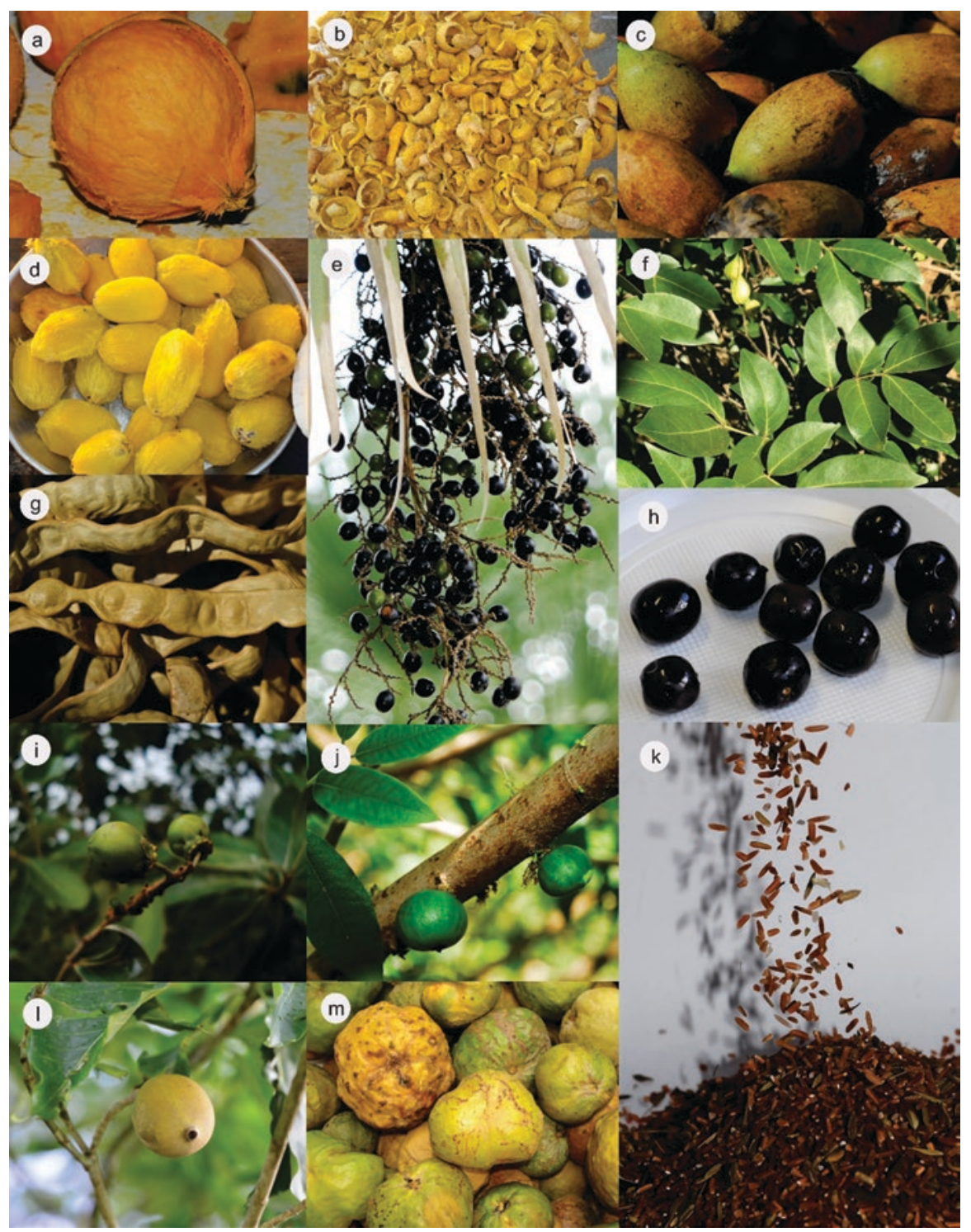

Fig. 1 Fruits and seeds of wild food plants from the Pantanal. (a) A. aculeata (fruits); (b) A. aculeata (pulp); (c) A. phalerata (fruits); (d) A. phalerata (seeds); (e) C. alba (fruits); (f) I. laurina (fruit); (g) P. ruscifolia (fruits); (h) V. cymosa (fruits); (i) Byrsonima cydoniifolia (immature fruits); (j) Plinia cauliflora (immature fruit); (k) O. latifolia (grains; (l) G. americana (fruit); (m) P. glomerata (fruits). (Pictures by Paulo Robson de Souza, except $\mathbf{f}$ (A. Pott) and $\mathbf{b}, \mathbf{d}$, and $\mathbf{m}$ (Ieda Maria Bortolotto)) 
of $A$. aculeata stipes was recorded for the Ayoreo people of the Paraguayan Chaco (Schmeda-Hirschmann 1994). Women of the Terena indigenous ethnicity in Mato Grosso do Sul consumed the heart of palm of Acrocomia spp. after childbirth to stimulate milk production (Oberg 1949). In general, the main alimentary uses are the fruits and heart of palm. It is the species with the highest use value in rural communities in the western edge on the Pantanal (Bortolotto et al. 2015).

\section{Nutritional Composition Data}

The edible portion composed of pulp and nut of A. aculeata represents circa $48 \%$ of the total fruit weight; the pulp is rich in total lipids, carbohydrates, fibers, and $\beta$-carotene, with considerable concentration of potassium, calcium, and phosphorous, showing to be a fruit with excellent yield and nutritive value for consumption in natura or in culinary (Prates et al. 2015). The pulp oil has an intense orange color characterized by the presence of carotenoids and high concentration of oleic acid (Hiane et al. 2005; Ramos et al. 2007). The nut oil is transparent, with a predominance of oleic and lauric fatty acids (Prates et al. 2015). The oils of both pulp and nut are also utilized for consumption or in pharmaceutical and cosmetic industries (Ciconini et al. 2013).

Regarding its nutritional composition, A. aculeata fruit pulp contains $52.99 \%$ moisture, $22.10 \%$ of carbohydrates, $8.14 \%$ of lipids, $1.50 \%$ of protein, $13.76 \%$ of fibers, and 167.67 calories in $100 \mathrm{~g}$ of pulp. The fresh pulp presents high concentrations of calcium $61.96 \mathrm{mg} / 100 \mathrm{~g}$, phosphorous $36.70 \mathrm{mg} / 100 \mathrm{~g}$, and potassium $766.37 \mathrm{mg} / 100 \mathrm{~g}$ and lower concentrations of sodium $3.74 \mu \mathrm{g} / \mathrm{g}$, iron $7.81 \mu \mathrm{g} / \mathrm{g}$, manganese $138 \mu \mathrm{g} / \mathrm{g}$, zinc $6.02 \mu \mathrm{g} / \mathrm{g}$, and copper $2.43 \mu \mathrm{g} / \mathrm{g}$. This fruit is also rich in $\beta$-carotene $(49.0 \mu \mathrm{g} / \mathrm{g}$ of pulp), contributing to the enrichment of the regional diet (Ramos et al. 2008).

\section{Attalea phalerata Mart. ex Spreng. Characteristics and Traditional Uses}

Attalea phalerata is a palm locally known as acuri or bacuri (Table 1). It is widespread from Brazil to Peru, occurring in several physiognomies in the Pantanal, mostly in monodominant formations called acurizal (Table 1). The fruit is an ellipsoid drupe of approximately $5 \mathrm{~cm}$ long, green when immature and yellow when ripe (Fig. 1c). The fruits have fleshy mesocarp, yellowish when ripe (Fig. 1d).

The pulp (ripe or green), as well as the nut of the fruits, is edible; the oil obtained from the nut, the flour made from the mesocarp, and the heart of palm have traditional uses in the diet (Table 1). The coco water of immature fruits can also be consumed (Pott and Pott 1994). The edible oil extracted from the nut was not mentioned in recent ethnobotanical works in the Pantanal but has economic importance in Bolivia (Moraes et al. 1996). The use of fruits (nut and pulp) and heart of palm in the diet and the utilization of chicha, an alcoholic drink (used only in the past), is associated with the Guató and Bororo indigenous culture in the Pantanal (Schmidt 1942; Hartmann 1967; de Oliveira 1996). 


\section{Nutritional Composition Data}

The potential of the nut protein (de Lima Mendes Ramos et al. 2017) and the pulp oil (de Lima et al. 2016, 2018) of A. phalerata fruit has been explored in experimental research. The ripe fruits of $A$. phalerata have a pulp rich in carotenoid pigments (pro-vitamin A), copper, and magnesium (Hiane et al. 2010). Additionally, the pulp lipidic fraction presents fatty acids with a predominance of oleic and palmitic acids, which can have considerable anti-inflammatory effects with potential nutraceutical properties (Freitas de Lima et al. 2017); it also has cytoprotective activity, probably for its capacity to inhibit the action of free radicals (de Lima et al. 2018). The fruit nut has high oil content and is rich in phosphorous and a source of iron (Hiane et al. 2010). The oleic and lauric fatty acids were the main compounds found in the nut oil (da Silva Baldivia et al. 2018). In Bolivia, the oil extracted from the nut (60-70\% of dry weight) is rich in lauric and myristic fatty acids, comparable with other tropical oil crops (Moraes et al. 1996).

Regarding nutritional composition, the pulp of $A$. phalerata presents $56.90 \mathrm{~g} / 100 \mathrm{~g}$ of moisture, $35.13 \mathrm{~g} / 100 \mathrm{~g}$ carbohydrates, $5.97 \mathrm{~g} / 100 \mathrm{~g}$ lipids, and low levels of ashes (1.25 g/100 g) and protein (0.75 g/100 g) (Siqueira et al. 2016).

\section{Copernicia alba Morong Characteristics and Traditional Uses}

Copernicia alba is a palm locally known as carandá (Table 1). It has occurrence in Brazil, Bolivia, Argentina, and Paraguay in South America (Table 1). In Brazil, it occurs only in the Pantanal, mostly in monodominant formations called carandazal (Table 1). The fruit is globous to ovoid, of approximately $1.2 \mathrm{~cm}$ in diameter, green when immature and black when ripe, with one seed (Moraes 2014). The fruits have a fleshy mesocarp, dark brown or almost black when ripe (Fig. 1e). The fruits ripen over an extended period, between April and November; some trees keep fruits until January (Silva 2018). The fruit production is considered high, more than $20 \mathrm{t} / \mathrm{ha}$ (Silva 2018).

The ripe pulp and the heart of palm have traditional uses in the diet in Porto Murtinho (Table 1). C. alba is gathered by the Ayoreo of the Paraguayan Chaco; the heart of palm is eaten raw or cooked in water or in ashes, and the palm ashes were used as a salt substitute (Schmeda-Hirschmann 1994; Peña-Chocarro et al. 2006), made from the burned spathe; the heart of palm is also consumed baked or ground as a flour (Peña-Chocarro et al. 2006). The Toba and Whichí of the Paraguayan Chaco consume the fresh fruits, and the Lengua-Maskoy ferment them to prepare

aloja (Peña-Chocarro et al. 2006). The apex extracted from the local palm C. alba was mentioned for use by the Chorote Indians in Argentina although unexploited at present (Arenas and Scarpa 2007). A liquor was developed from the pulp of fruits harvested (Silva 2018).

\section{Nutritional Composition Data}

In the pulp of $C$. alba collected in Corumbá and Porto Murtinho, a moisture content of 54.12\%; good levels of total carbohydrates $(27.92 \%)$, lipids $(6.03 \%)$, and proteins (3.39\%); energetic value of $232.8 \mathrm{Kcal} / 100 \mathrm{~g}$; and considerable content of 
ashes (3.71\%), with considerable potential for food products (Silva 2018). The contents of lipids are around $48 \%$ in seeds of ripe fruit and $40 \%$ in the immature; in contrast, the peel of the ripe has a lower fat level $(0.5 \%)$ than in the immature fruit $(0.8 \%)$, and in the pulp, both values are very low $(0.1 \%)$ (Silva 2018). The fruit contains bioactive phenolic and medicinal compounds and unsaturated fatty acids (Silva 2018). Furthermore, the fruit has high vitamin C content, of $20.5 \mathrm{mg} / 100 \mathrm{~g}$, equivalent in the peel and the pulp (Silva 2018), thus, a valuable raw matter for functional foods as an antioxidant source.

In a province in Argentina, the values found in this fruit seem discrepant, consisting in $4.70 \%$ moisture, $82.80 \%$ total carbohydrates, $24.30 \%$ crude fiber, $1.90 \%$ lipids, $8.60 \%$ proteins, and $6.70 \%$ ashes. The fruit was rich in minerals such as sodium $(31.13 \mathrm{mg} / 100 \mathrm{~g})$, potassium $(856.83 \mathrm{mg} / 100 \mathrm{~g})$, magnesium $(54.96 \mathrm{mg} / 100 \mathrm{~g})$, calcium $(98.73 \mathrm{mg} / 100 \mathrm{~g})$, and expressive levels of iron $(1.37 \mathrm{mg} / 100 \mathrm{~g})$, manganese $(0.72 \mathrm{mg} / 100 \mathrm{~g})$, and zinc $(0.29 \mathrm{mg} / 100 \mathrm{~g})$ (Gorostegui et al. 2011). However, because the analyses in the Brazilian study were expressed on a fresh basis and the Argentinian one on a dry basis, the discrepant values of nutritional composition between the studies are justified and also can be further explained by differences between regions where the fruits were collected since factors such as soil and climate influence its composition.

\section{Fabaceae \\ Inga laurina (Sw.) Willd. Characteristics and Traditional uses}

Inga laurina, known as ingá, is a tree species widely distributed in South and Central America (Table 1). Its fruits are plane to convex pods (flat to convex) (Fig. 1f), margins slightly raised or not, glabrous, and yellowish to green-yellowish color (Pennington 1997), which varies with the degree of ripening (Martins et al. 2014). The edible part of the fruit is a white sarcotest, commercialized in El Salvador (Pennington 1997), and has sweetish taste. In the Pantanal, they are consumed in natura (Table 1). It has potential for various culinary uses (Kinupp and Lorenzzi 2014), as well as other species of the genus, such as I. vera Willd. (Bortolotto et al. 2017). I. vera is a species that also occurs in the Pantanal, even more common and more abundant than I. laurina, forming monodominant populations especially in the riparian forests of the Paraguay River and affluents, with fruits mainly in the flood season (Damasceno-Junior et al. 2005). However, nutritional data are yet lacking on I. vera.

\section{Nutritional Composition Data}

The fruit of I. laurina has the shape of a slightly curved pod; the peel is thin, with green-yellow color, which varies with the degree of ripening (Schulz et al. 2014). The fruits of I. laurina are constituted by pulp (41\%), peel (39\%), and seed (20\%). For industrial use, higher pulp yields are obtained when optimizing the selection for more fresh mass and fruit length, once they are good indicators of the high association of these characteristics with pulp yield (da Silva Oliveira et al. 2019). 
Regarding nutritional values, I. laurina fruit has high moisture content (85.39\%); thus, it is more prone to deterioration. It has $81.91 \mathrm{Kcal} / 100 \mathrm{~g}$ of energy value; low contents of proteins $(0.13 \mathrm{~g} / 100 \mathrm{~g})$, lipids $(0.0007 \mathrm{~g} / 100 \mathrm{~g})$, and ashes $(0.14 \mathrm{~g} / 100 \mathrm{~g})$; and expressive values of carbohydrates $(13.52 \mathrm{~g} / 100 \mathrm{~g})$. For containing high levels of phenolic compounds (110.67 mg GA $100 \mathrm{~g}$ ) and considerable quantities of vitamin C (1.60 mg AA $100 \mathrm{~g}$ ), the fruit can be considered having a promising antioxidant potential (de Lima and Portari 2019).

When compared with the conventional apple (Malus domestica Borkh.), widely commercialized in Brazil, I. laurina contains high levels of phenolic content. Moreover, for its functional properties to health, it is advisable to stimulate the development of products by pharmaceutical and food industries and to promote the sustainable utilization of native fruits in areas with easier access, for both consumers and industries (de Siqueira et al. 2013).

\section{Prosopis ruscifolia Griseb. Characteristics and Traditional Uses}

Prosopis ruscifolia, known as algarrobo, is a tree species, also belonging to the Fabaceae family. It has occurrence in Brazil, Bolivia, Argentina, and Paraguay in South America (Table 1). In Brazil, it occurs in the Caatinga and in the Pantanal (de Souza-Lima et al. 2017) (Table 1). The fruit is a drupaceous loment (Noguchi et al. 2009) (Fig. 1g) ripe in the dry months (Table 1). The sweetish fruits (Pott et al. 2004) have known traditional food uses for production of flour, preparation of bread and cakes, and an alcoholic drink (chicha) (Table 1). These were mentioned as food when going to the field, for example, and are used sporadically (Bortolotto et al. 2019). The seeds of $P$. ruscifolia are edible, roasted, and grinded (Boeri 2016). Other three species with edible fruits, . alba Griseb, P. nigra Hieron., and P. Hassl., were also recorded for the Brazilian Chaco in the municipality of Porto Murtinho (Sartori et al. 2018). An algarroba beer prepared from fruits of P. alba, the "aloja de algarroba" (in local Spanish), is an ancient alcoholic drink of the Whichís (Argentina and Bolivia) (Cano et al. 2020) and other indigenous peoples from the Gran Chaco in South America (Arenas and Scarpa 2007).

\section{Nutritional Composition Data}

The fruit of $P$. ruscifolia is an excellent source of proteins $(12.7 \mathrm{~g} / 100 \mathrm{~g})$ and has high content of carbohydrates $(78.5 \mathrm{~g} / 100 \mathrm{~g})$, lipids, $(4.32 \mathrm{~g} / 100 \mathrm{~g})$ and fibers (17.8 g/100 g) (Freyre et al. 2003) (Table 2). It has been shown (Freyre et al. 2003) (Table 2) that the pulp flour contains a nutritional complement of adequate amino acids; thus, it is a fruit with high biological value proteins as a food and also for enrichment of food products. For the digestibility nearly complete in the gastrointestinal tract, the flour has a low allergenic potential (Mamone et al. 2019).

Regarding micronutrients, the seeds have an excellent content of iron $(4.57 \mathrm{mg} / 100 \mathrm{~g})$, zinc $(3.89 \mathrm{mg} / 100 \mathrm{~g})$, considerable values of calcium $(1.528 \mathrm{mg} / 100 \mathrm{~g})$, phosphorous $(4.719 \mathrm{mg} / 100 \mathrm{~g})$, and potassium $(5.887 \mathrm{mg} / 100 \mathrm{~g})$ (Freyre et al. 2003). For its high iron content, the fruit can be consumed with other foods (lemon, orange, and guava) that have ascorbic or citric acid to increase the 
availability of iron, thus, helping in an adequate and healthy diet (Bernardi et al. 2004).

\section{Lamiaceae \\ Vitex cymosa Bertero ex Spreng Characteristics and Traditional Uses}

Vitex cymosa, known as tarumã, is a tree belonging to the family Lamiaceae, with wide occurrence in Brazil and several countries of South and Central America (Table 1). The fruit is a globous drupe, with dark red or purple color at ripening (Fig. 1h). Its pulp is mucilaginous and juicy and has a sweetish taste. The fruits are abundant and cover the ground at maturity time (November to February) (Table 1). Besides traditional uses in the diet, for consumption in natura or as jam (Table 1), the ripe fruit has a potential to aromatize salty dishes, especially meats (DamascenoJunior and Souza 2010). Although the fruit has a very strong sour-sweetish smell, unpleasant to some people, from it can be produced a syrup with economical potential for use in the cover of ice creams and cakes.

\section{Nutritional Composition Data}

Vitex cymosa fruit has a high moisture content $(83.74 \mathrm{~g} / 100 \mathrm{~g})$ that can cause fast deterioration since the proliferation of microorganisms is favored and consequently hinders fruit quality. In $100 \mathrm{~g}$ of whole fruits, low content of lipids $(0.03 \%)$ and proteins $(0.49 \%)$ were observed; however, it presents considerable values of total carbohydrates $(9.34 \%)$ and fibers $(4.66 \%)$. The fruit of $V$. cymosa is considered a food of low caloric value $(36.6 \mathrm{kcal} / 100 \mathrm{~g})$. However, the fruit is rich regarding micronutrients, potassium $(287.8 \mathrm{mg} / 100 \mathrm{~g})$, phosphorous $(21.1 \mathrm{mg} / 100 \mathrm{~g})$, and iron $(0.43 \mathrm{mg} / 100 \mathrm{~g})$, as well as vitamin $\mathrm{C}$ for children of $1-3$ years of age and a source of fiber for children and adults (Caldeira et al. 2004). That was corroborated by results of fruits analyzed in Ecuador, showing that phosphorous and potassium were the main macro-minerals found in natura fruits (Guevara et al. 2020).

\section{Malpighiaceae \\ Byrsonima cydoniifolia A. Juss.}

\section{Characteristics and Traditional Uses}

Byrsonima cydoniifolia, locally known as canjiqueira, is shrub or treelet that belongs to the Malpighiaceae. It occurs in several countries of South and Central America and most of Brazil (Table 1). It occurs in monodominant formations in the Pantanal (Pott and Pott 1994) and the Araguaia wetland (Brazil) (Marimon and de Souza Lima 2001). The fruits are globose, drupaceous, and juicy and measure circa $2 \mathrm{~cm}$ diameter, with color varying from yellow to orange when ripe (Fig. 1i). Besides the traditional consumption of the fruit pulp in natura in the Pantanal (Table 1), it can be used to prepare liquor, jam, ice cream, and sweets.

\section{Nutritional Composition Data}

The fruit composition of B. cydoniifolia revealed $655.5 \mathrm{~g} / \mathrm{kg}$ moisture, $47.42 \mathrm{~g} / \mathrm{kg}$ carbohydrates, and $252.6 \mathrm{~g} / \mathrm{kg}$ de lipids; furthermore, the fruit presented $45.9 \mathrm{~g} / \mathrm{kg}$ carotenoids and $1.82 \mathrm{~g} / \mathrm{kg}$ ascorbic acid, showing to be a fruit with high antioxidant 


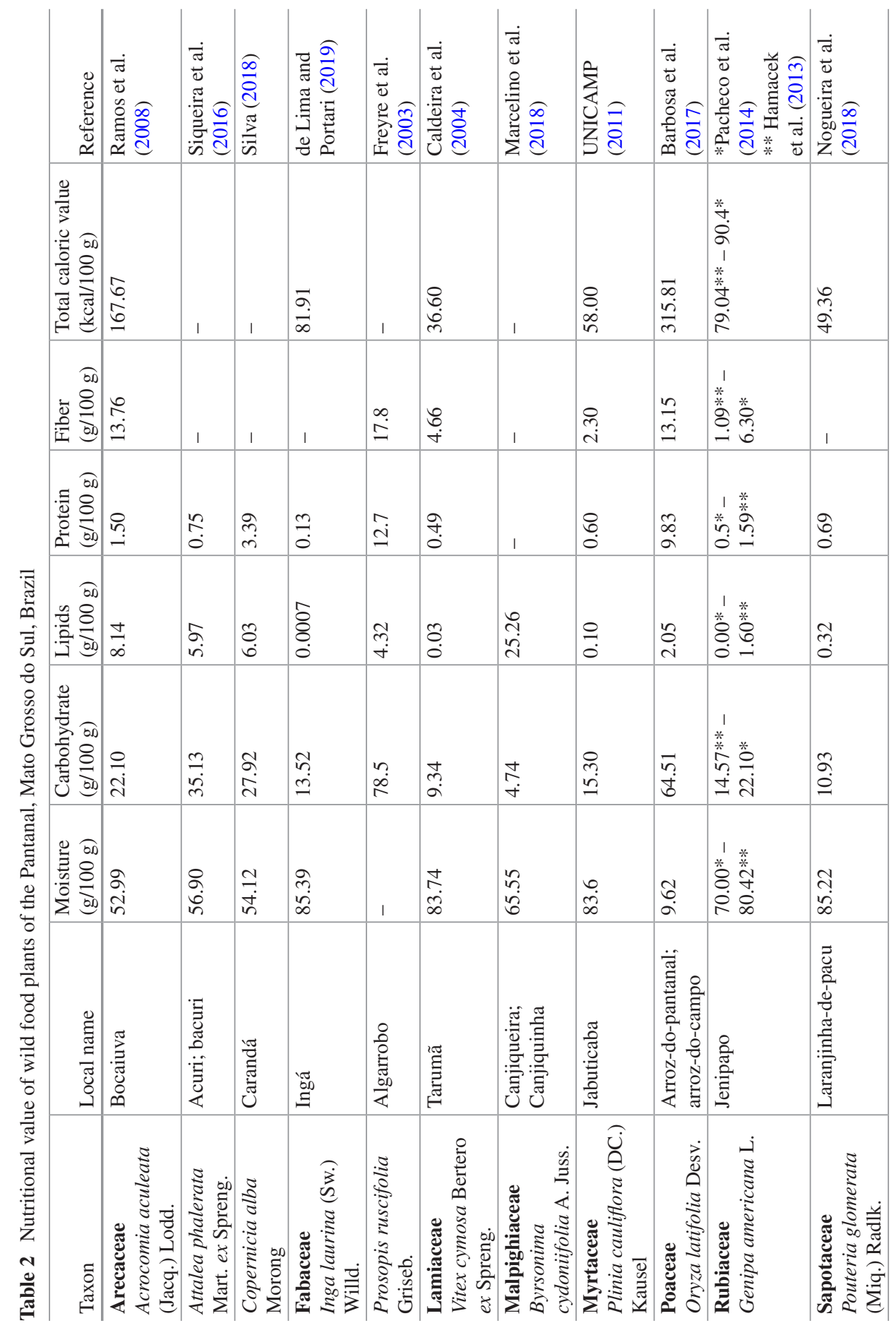


activity (Marcelino et al. 2018). These results show that knowing the nutritional properties of native fruits allows indicating their consumption in natura or as culinary ingredients; besides, the regular consumption of fruits with a considerable content of antioxidant compounds, such as B. cydoniifolia, prevents chronic non-communicable diseases (Gonzalez 2006).

Chemical analyses of the fruit composition of B. cydoniifolia showed derivatives of flavonoids and stilbenes, such as trans-piceatannol and resveratrol as the main secondary metabolites, demonstrating their anti-inflammatory and anti-hyperalgesic effect and sustaining its potential as a nutraceutical food (dos Santos et al. 2017). The fruits of $B$. cydoniifolia have potential as functional ingredients, and the oil has potential for edible uses (Marcelino et al. 2018). The pulp and the seed are significant sources of potassium and sodium, the seed having higher concentrations of calcium, copper, iron, manganese, magnesium, selenium, and zinc (Arakaki et al. 2020). Jam is an excellent alternative for the utilization of $B$. cydoniifolia fruits, due to the reduction of antinutritional factors and retention of bioactive compounds in processing this product (Prates et al. 2015).

\section{Myrtaceae}

\section{Plinia cauliflora (DC.) Kausel}

\section{Characteristics and Traditional Uses}

Plinia cauliflora (Myrciaria cauliflora (Mart.) O. Berg), the jabuticaba, is a treelet circa $6 \mathrm{~m}$ tall, of the Myrtaceae family, and occurs in South, Central, and North America (Table 1), often grown in home gardens. Many Neotropical Myrtaceae have edible fruits. The fruit is a globose berry with approximately up to $5 \mathrm{~cm}$ in diameter (Fig. 1j), green when immature and purple when ripe. The pulp is whitish, soft, and sweet. The fruits have traditional consumption in natura and also as jams, vinegar, and liquor (Table 1). The fruits must be harvested fully ripe (soft), but for transport and storage, it is necessary to harvest them just before ripening (Damasceno-Junior and Souza 2010).

\section{Nutritional Composition Data}

For being widely consumed in Brazil, the nutritional composition of P. cauliflora is shown in the nutritional table of UNICAMP (2011); $100 \mathrm{~g}$ of fruit have contents of energy of $58 \mathrm{kcal}, 0.6 \mathrm{~g}$ proteins, $0.1 \mathrm{~g}$ lipids, 15.3 total carbohydrates, and $2.3 \mathrm{~g}$ fibers. Regarding micronutrients, the fruit presents a high level of potassium $(130 \mathrm{mg})$ and considerable levels of calcium $(8 \mathrm{mg})$ and phosphorous (15 mg) (UNICAMP 2011).

Biazotto et al. (2019) evidenced in P. cauliflora high contents of carotenoids $(326.70 \mu \mathrm{g} / 100 \mathrm{~g}$ ) and total phenolics (109.65 mg GAE/100 g EF). Thus, their study demonstrated that this fruit represents an excellent resource with a technological and economic potential of bioactive compounds found in the Brazilian biodiversity of unexplored fruits, mainly in the nutritional and pharmaceutical areas.

An analysis of two cultivated varieties of $P$. cauliflora in Minas Gerais (Brazil) showed high contents of minerals, $2.75 \mathrm{~g} / 100 \mathrm{~g}$ in Paulista and $3.82 \mathrm{~g} / 100 \mathrm{~g}$ in 
Sabará; in both, the component of insoluble fibers of $2.57 \mathrm{~g} / 100 \mathrm{~g}$ and $3.30 \mathrm{~g} / 100 \mathrm{~g}$ is higher than the soluble ones (de Lima et al. 2008).

\section{Poaceae \\ Oryza latifolia Desv. \\ Characteristics and Traditional Uses}

Oryza latifolia is an emergent aquatic herb, approximately $2 \mathrm{~m}$ tall, perennial, belonging to Poaceae, the grass family (Pott and Pott 2000). This wild rice occurs in several countries of South and Central America (Table 1). In the Pantanal, it occurs in monodominant stands called arrozal in the floodplain of the Paraguay River (Bertazzoni and Damasceno-Júnior 2011). The grains are of the "agulhinha" type, small and reddish (Fig. 1k), with almond-like flavor. The rice ripens at the flood peak in the Pantanal (Table 1). Its cultural alimentary value is associated with indigenous people (Guató) from the Pantanal, but it has no longer been used in their diet (Bortolotto et al. 2015).

It is a species that can occupy extensive areas over the floodplain of the Paraguay River in years of more intense flooding. There are other four species of Oryza in the Pantanal: O. alta Swallen, O. glumaepatula Steud., and O. grandiglumis (Döll) Prod. (Filgueiras et al. 2015; Flora do Brasil 2020). Among these, O. glumaepatula presents high levels of total fractions of protein, albumin, and glutelin (protein, albumin, and glutelin fractions) (Santos et al. 2013).

\section{Nutritional Composition Data}

Its whole grain contains $9.62 \%$ moisture, $2.05 \%$ lipids, $9.83 \%$ proteins, $64.51 \%$ starch, $13.15 \%$ fibers, and $315.81 \mathrm{kcal}$ of energy; these values are similar to Oryza sativa L., the commercial rice, a staple food in Brazil (Barbosa et al. 2017).

\section{Rubiaceae \\ Genipa americana $\mathrm{L}$. Characteristics and Traditional Uses}

Genipa americana, jenipapo, is a tree belonging to the Rubiaceae family (Table 1). It has a wide distribution in Central and South America, including most of Brazil (Table 1). It is a dioecious species, i.e., only the female plant fructifies. The fruit is an oval berry (Fig. 11) circa $8 \mathrm{~cm}$, brownish when ripe. The pulp is spongy, juicy, and sweet, traditionally consumed in natura and as for sweets and juices (Table 1).

For being an easily perishable fruit, with peculiar sensorial characteristics that reduce its acceptability in natura, thus, aiming to avoid losses and increase the potential of its consumption, strategies that help its conservation and acceptance are searched, such as drying by osmotic dehydration using an osmotic agent, such as sugar, increasing the shelf life, palatability, and acceptance in comparison with the in natura fruit (Andrade et al. 2003).

\section{Nutritional Composition Data}

Regarding chemical composition, G. americana presents $70 \%$ moisture, $22.1 \%$ carbohydrates, $0.0 \%$ lipids, $0.5 \%$ proteins, and $6.3 \%$ alimentary fibers, besides 
$2.0 \mathrm{mg} / 100 \mathrm{~g}$ de vitamin C, $176.3 \mathrm{mg} / 100$ phenolic compounds, and 70.2\% of antioxidant capacity (Pacheco et al. 2014). Another nutritional study that also assessed the G. americana fruit found $80.42 \mathrm{~g} / 100 \mathrm{~g}$ moisture, $14.57 \mathrm{~g} / 100 \mathrm{~g}$ carbohydrates, $1.60 \mathrm{~g} / 100 \mathrm{~g}$ lipids, $1.59 \mathrm{~g} / 100 \mathrm{~g}$ protein, $1.09 \mathrm{~g} / 100 \mathrm{~g}$ fibers, and total energetic value of $76.92 \mathrm{kcal} / 100 \mathrm{~g}$ (Hamacek et al. 2013). Thus, G. americana is a fruit with considerable nutritional values, besides high antioxidant capacity, and its inclusion in the regional diet is indicated. The fruit contains essential oil, tartaric acid, and glucose (Prance 1989).

\section{Sapotaceae}

\section{Pouteria glomerata (Miq.) Radlk.} Characteristics and Traditional Uses

Pouteria glomerata is a tree of the Sapotaceae family, locally known as laranjinha-de-pacu (Table 1), in allusion to its use as fishing bait. It occurs in several countries of South and Central America, frequently found in Pantanal riparian forests (Table 1). The fruits are fleshy, globose berries, with green peels when immature and yellow when ripe. It can present the shape of a squash pumpkin (undulated), and so it also receives the name of moranguinha (Fig. 1m). The edible part is the pulp, with a pleasant acid taste, traditionally consumed in natura (Table 1). For its acidity (presence of tartaric and malic acids) and pectin content, it forms a gel, being excellent to prepare jams. It has been utilized for the production and commercialization of frozen pulp for juices, popsicle, ice cream, and jams (Bortolotto et al. 2017) or sold in natura (Damasceno-Junior and Souza 2010).

\section{Nutritional Composition Data}

The pulp of this fruit contains $85.22 \%$ moisture, $10.93 \%$ carbohydrates, $0.32 \%$ lipids, $0.69 \%$ proteins, $0.64 \%$ ashes, $4.94 \%$ tilted acidity, and $3.19 \mathrm{pH}$ (Nogueira et al. 2018). P. glomerata, besides vitamin C (34.87 mg/100 g), can be considered an excellent source of bioactive compounds, with antioxidant potential attributed to its phenolic compounds, anthocyanins $(0.65 \mathrm{mg} / 100 \mathrm{~g})$, carotenoids $(0.93 \mathrm{mg} / 100 \mathrm{~g})$, and flavonoids $(9.63 \mathrm{mg} / 100 \mathrm{~g})$, with beneficial effects on human health (Teixeira et al. 2020).

\section{Discussion}

The results show that the selected food plants in this work have rich nutritional values, wide geographical distribution, and abundance in the native physiognomies, with available nutrients spread over the year (Table 1). These species have been the target of projects that incentivize their utilization in communities of various municipalities. The combination of vast populations of the native species here presented with high production of fruits and high nutritional value offers support to nutritional security most of the year. 


\subsection{Nutritional Value}

The three species of the Arecaceae family, A. aculeata, A. phalerata, and C. alba, have abundant fruits over a great part of the year and wide distribution in the Pantanal (Table 1), besides the heart of palm, little used. The endosperms of the A. aculeata and $A$. phalerata represent excellent sources of calories and edible oil for the local diet (Table 2), especially of the oleic and lauric fatty acids (Hiane et al. 2005; da Silva Baldivia et al. 2018). A. aculeata is rich in $\mathrm{Mn}, \mathrm{Cu}, \mathrm{P}, \mathrm{Mg}$ (nut), $\mathrm{Cu}$, and pro-vitamin A (pulp) (Hiane et al. 2010), what certainly justifies its broad use by the human populations, with the highest value of local use among the native food species, either in the present or in the past (Herberts 1998; Bortolotto et al. 2015).

Vitamin A is an essential component in the diet, and its deficiency still is a public health problem in several places in the world (Greiner 2013). Its availability to the rural human populations is a relevant health factor. A recent study evaluated the deficiency of vitamin A (DVA) in children and the associated factors, including all Brazilian regions, including the Central-West where the Pantanal is, in both rural and urban areas (Lima et al. 2018). Those authors found that DVA prevailed in the urban zone, even that the population resident in the rural zone presents a higher vulnerability to nutritional deficiencies at the world level. Considering that the precursors of vitamin A, mainly $\beta$-carotene, are found in the fruits of A. aculeata and A. phalerata, their continuity in the diet ought to be stimulated. Moreover, the fatty acids found in nuts of $A$. phalerata are important regulators of the metabolism and are frequently associated with a reduction of serum cholesterol and body fat and a lower risk of developing cardiovascular diseases (da Silva Baldivia et al. 2018).

In general, the fruits of $V$. cymosa, G. americana, I. laurina, and P. glomerata present nutritional compositions with reduced values of lipids and considerable quantities of ashes, moisture, and carbohydrates. B. cydoniifolia has slightly higher contents of lipids than those fruits. $O$. latifolia contains a higher protein level, and the palms $A$. aculeata and $A$. phalerata show significant values of proteins and lipids, plus other constituents. Besides these nutrients, all fruits exhibit phenolic compounds and vitamin $\mathrm{C}$ and carotenoids, especially the orangish fruits, which contain bioactive compounds with antioxidant properties. For the antioxidant action to occur, it needs to inhibit or impede the auto-oxidative process caused by free radicals, besides having stability about their intermediate compounds formed (Finco et al. 2012). P. ruscifolia fruit has a high alimentary and technological potential for the traditional communities of the Chaco since its nutritional composition is rich in several nutrients that help in the human body organic functions, besides the food security of communities more susceptible to nutritional deficiencies.

It is known that a diet containing essential nutrients and with the addition of substances of nutraceutical potentials, in a healthy lifestyle, can exert a fundamental role in prevention and or treatment of non-communicable diseases (Pereira and Cardoso 2012) and other illnesses, e.g. severe acute respiratory syndrome coronavirus 2 (SARS-CoV-2) caused by the coronavirus 2019 (COVID-19) (de Faria CoelhoRavagnani et al. 2020). 
The nutritional status of people infected by SARS-CoV-2 is indispensable to indicate a better prognostic and can influence the severity of the condition. The supplementation from a diet rich in probiotics, vitamins, and minerals does not act preventively neither in the treatment of the infection by COVID-19 but can improve the immune response in an auxiliary way. As such, the intake of vitamins $\mathrm{C}$ and $\mathrm{D}$, zinc, and selenium is beneficial to individuals with or under risk of viral respiratory infections (de Faria Coelho-Ravagnani et al. 2020).

In Brazil, the most immediate consequence of the health crisis caused by COVID-19 pandemic is the worsening of food insecurity due to income restrictions limiting food access (da Silva Filho and Gomes Júnior 2020). Thus, incentives are needed to the consumption and valuation of native fruits available locally since most contain considerable quantities of vitamin $\mathrm{C}$ and other vital nutrients. With the social distance to slow the spread of COVID-19, the search for local products is being driven by economic reasons in evaluating the consumption of seasonal and regional foods, once these fruits are available to the local community.

\subsection{Geographic Distribution and Abundance of WFP in Native Vegetation}

Most food species of this chapter occur in several phytogeographic domains in South and Central America (Table 1) and are part of the food culture there, besides the Pantanal. That is especially evident in the neighboring countries Bolivia and Paraguay, with similar recorded uses to the mentioned for the Pantanal for species such as A. aculeata and A. phalerata, with production of oil, flours, and other products (Schmeda-Hirschmann 1994; Moraes et al. 1996). The fruits as the most important species culturally can be obtained over all months of the year (Table 1), what is strategic in terms of food and nutrition security and food sovereignty for the local populations.

Moreover, several species mentioned here as the most important culturally have high nutritional value and are abundant in the Pantanal. B. cydoniifolia, A. phalerata, C. alba, and O. latifolia grow as monodominant formations (Table 1), besides the occurrence of Inga vera. Monodominant formations are vegetation types characterized by the dominance of a single species, generally over $50 \%$ of the individuals or the cover (Hart 1990). One of the causes of monodominance in wetlands is the flood (Hart 1990). The names of these formations are associated with the local names of the species names: canjiqueiral, the formation of B. cydoniifolia, acurizal of A. phalerata, carandazal of $C$. alba, and arrozal of O. latifolia (DamascenoJunior et al. (in press)). B. cydoniifolia is a pioneer species with high capacity to colonize open environments such as grasslands, a process called encroachment (Barbosa da Silva et al. 2016). Many ranchers control such species that take over native grasslands, e.g., $B$. cydoniifolia is cut before the flood or pulled down by 
tractors (Pott and Pott 1994). The occupation of A. phalerata and the abundance of A. aculeata are also associated with disturbed areas.

Indeed, all these species seem monocultures for the characteristics of their occurrence. Given their nutritional value, they constitute a great opportunity for utilization as a source of alternative income for rural properties and for local communities. Every year these species produce tons of products such as fruits and grains without an associated productive chain yet. As an aggravating factor, stands of valuable plants are eliminated in favor of grasslands. The use of these species by traditional communities and rural properties can configure an excellent opportunity for conservation of these ecosystems, as well as can offer unique products and could receive the denomination of origin, for example.

\subsection{Products and Services Associated with Conservation (Sustainable Use) and Innovation}

The use of wild foods, especially in low-income rural communities, which still have access to the biodiversity and detain knowledge on how to use it, is a strategy that can be very important for the food security under risks of climatic changes (Smith et al. 2019) and to improve health in the face of the COVID-19 pandemics, as mentioned earlier. Knowledge on the nutritional value of these fruits gives support to public policies that promote the sustainability for their subsistence, mainly in the aspect of food security of the Pantanal riverine communities.

Despite abandoning the use of traditional ( $O$. latifolia) or neglected species (e.g., oil of palms), considering their abundance and wide distribution, they can still supply the daily dietary needs of the populations, especially those under food shortage. The situation of neglected food species and the need for initiatives to improve the acceptance of wild foods is under discussion in ethnobotanical studies (do Nascimento et al. 2013). In Brazil as well as in other South American countries, there are already advances aiming to conserve the culture and biodiversity associated with incentives to the use of native flood plants (May and da Vinha 2013; Depenthal and Meitzner Yoder 2017).

The Universidade Federal de Mato Grosso do Sul and several partners have projects in this line such as the program "Sabores do Cerrado \& Pantanal" (Bortolotto et al. 2017) to strengthen technological practices to aggregate value in the income of traditional riverside communities, besides promoting knowledge in the academic area, qualification of the external community, symposia, and courses on the valuation of food plants of the Cerrado and Pantanal. Research and extension actions were developed in the last 15 years to incentive the consumption of native species abundant in the Pantanal, with cultural bound and with potential to improve the income of small communities (Damasceno-Junior and Souza 2010; Bortolotto et al. 2017). Thereby, the utilization commercialization (to obtain income) in small communities of the Pantanal was awakened and started a process of cultural rescue with 
incentives to the use in the local diet that has to be associated with the conservation of biodiversity and sustainable development (Candil et al. 2007).

Although neglected in the past century by the big market and without attention from public policies aiming their scientific study until the middle of the 1980 decade, the native species have gained importance over the last years, following a worldwide movement related to the use of wild food plants (Termote et al. 2011; Menendez-Baceta et al. 2012; Molina et al. 2012; Smith et al. 2019; Cano et al. 2020). However, they still need to be better explored in the nutritional aspect. Most are present in preparations of flours and oils or are tasty ingredients of ice creams, preserves, and other products. Thus, they deserve more attention as potential sources of nutrients, mainly in natura, and also as an income source for the population. The production of flours and oils is an essential strategy of the local populations to store foods for periods with low availability of the resources and for commercialization and to improve income.

The pulp flour A. phalerata, for example, is utilized for cakes, bread, and sauces; from the nut can be made coco sweet and extract edible oil. The pulp flour arises high interest for its nutritive value, consistency, taste, and flavor of excellent quality (Damasceno-Junior and Souza 2010). Recent studies showed that the pulp and the nut of $A$. phalerata are adequate ingredients for the formulation of müsli since they demonstrated improvement in the characteristics of color, texture, and nutritional and energetic value of the product compared with the analyzed commercial granola (Mendoza et al. 2016). I. laurina has functional properties for health, being important to stimulate the development of products in pharmaceutical and food industries, with sustainable use of the fruits (de Siqueira et al. 2013). Similarly, P. ruscifolia as well as other species of Prosopis have a high potential for food utilization (Boeri 2016). C. alba fruit has an excellent nutritional value with high vitamin $C$ and represents a great potential for new food products (Silva 2018).

Despite this potential for traditional utilization in the Pantanal and potential for innovation, the products are still not conventional in the big markets and somehow neglected, called unconventional food plants (UFP) (Kinupp and Lorenzzi 2014). An UFP can be exemplified by $B$. cydoniifolia, with relevant nutritional and nutraceutical value, but has been neglected. With adoption of sustainable technologies, it will be possible to innovate and to valorize the use of traditional wild food plants of the Pantanal and to conserve both biodiversity and culture. The identification of challenges and solutions able to influence practices in the chains of local supplies can favor the sustainability of the global production ecosystem (Tomas et al. 2019). The collaboration of scientific research represents an important role to play, besides actors outside the academy encompassing local communities, indigenous groups, manager agencies, non-government organizations or NGOs, big transnational corporations, and governmental actors. The consumers can also be influent in the promotion of sustainability, guiding their purchases with sustainable thinking (Nyström et al. 2019).

The market trend for growth of sustainable production and consumption stands out, besides some emergent questions ending up to insert, influence, or press for transformations in the ways of relationship with the environment, the form to 
produce, transform, and consume the foods (da Veiga Dias et al. 2015). Some actions were suggested to strengthen the initiative "Plants for the Future" of the Ministry for Environment: the incentive to actions that stimulate people to consume products from the native biodiversity, creating demand for new products and diversifying the diet of the families; the increase and promotion of the use of these species, also in school diets; and stimulation to higher participation of components of the native biodiversity in strengthening the national gastronomy (MMA 2016).

Family agriculture is conceived as the guardian of the biological diversity, being responsible for the introduction of new species of products from the native biodiversity in the commercial circuits of the agro-alimentary system, as well as supplier for cosmetic and pharmaceutical industries (Mendes et al. 2014). From the utilization of fruits of the Pantanal, new rural family enterprises and the traditional and extractivist communities can stand out in food production and increase their income, with increased quality of life and the potential of regional sustainable development. The socioeconomic and cultural potential of native plant species of the Pantanal is valuable, and it can contribute to the supply of new products with nutritional and functional quality, bringing benefit to consumer health.

The combination of large populations of the species with the high production of fruits with high nutritional value offers nutritional security in most part of the year. Considering only these 11 species (Tables 1 and 2), it is noticeable that the availability of fruits over the year can provide essential nutrients in nearly all months.

\section{Final Considerations}

Until recently, most morphotypes of bocaiuva palms were identified as A. aculeata, while $A$. totai was considered a synonym. Later, both species became valid again, with occurrence in Central Brazil (including Pantanal) (Lorenzi 2010). However, a morphometric and molecular investigation showed the species occurring in the Pantanal is A. totai, besides the very rare and newly described A. corumbaensis (Vianna and Campos-Rocha 2020). The scientific works about nutritional data compiled in this chapter refer to A. aculeata, most times to an herbarium voucher, but that has not been updated in herbaria, to differentiate A. aculeata from A. totai.

The botanical collection of palms is not a simple task, demanding a specific training; however, there is a strong recommendation that a voucher shall be deposited in herbarium to allow tracking the data. Studies on food plants or with food potential included in genera such as Oryza, Hymenaea, Campomanesia, Passiflora, and Arachis (Bortolotto et al. 2018) represented in the Pantanal by various species ought to fulfill this requirement. $O$. alta, for example, is considered a synonym of $O$. latifolia, but it is still accepted as a distinct species. Such taxonomic controversies are frequent until they are settled among specialists. Since many native species have gained visibility recently, by a function of the results of studies on the nutritional value of wild food plants so far neglected, there is still a need for taxonomic revisions of species with doubtful identification. Also, care should be taken when 
searching a plant in the literature since it may have been reported with a name that became a synonym and so is not retrieved, e.g., Scheelea phalerata, now Attalea phalerata.

However, such situation is not restricted to palms either to our work. Many reports on nutritional value did not indicate a herbarium specimen, despite the recommendations. The use of wild plants for food and nutrition requires precise data, reliable and accessible about their composition as the data users must be sure about the reliability of the identification and naming of flood plants (Nesbitt et al. 2010). Those authors analyzed the identification and nomenclature of plants in 50 articles referring to 502 sampled species, each one associated with one or more nutritional data. They noted that from the 502 sampled plants, only 36 followed the best practices for plant identification and recommend that researchers should identify, name, and publish the species correctly.

Given the relevance of the Central-West native species destined to food and health, generally produced and commercialized by small farmers and local communities, we suggested to research funding organs to direct resources and incentives to the priority native species in the scope of the initiative "Plants for the Future," including public policies, as well as to maximize the application of resources in multidisciplinary and multi-institutional network efforts (MMA 2016). We point out that among the 11 species selected for this chapter, only A. aculeata, P. cauliflora, G. americana, and O. latifolia were included in the proposed "Plants for the Future," demonstrating the need to improve knowledge about species of the Pantanal, which also have widespread occurrence and high food potential.

Acknowledgments To the Universidade Federal de Mato Grosso do Sul for infrastructure and support, we thank the Brazilian Coordination for the Improvement of Higher-Level Education Personal (CAPES) for scholarships to M. R. da S. Lopes and L. P. R. da Silva, Finance Code 001, and the Graduate Program in Health and Development in the Central-West - Universidade Federal de Mato Grosso do Sul - and to the National Council for Scientific and Technological Development (CNPq) for the researcher grants to G. A. Damasceno-Junior, process number 307429/2019-9 and A. Pott, process number 303191/2017-1. Special thanks to Prof. Dr. Paulo Robson de Souza who kindly provided images of fruits to compose Fig. 1.

\section{References}

Adámoli J (1982) O Pantanal e suas relações fitogeográficas com os cerrados: discussão sobre o conceito de complexo do Pantanal. In: Anais do $32^{\circ}$ Congresso nacional da Sociedade Botânica do Brasil. Universidade Federal do Piauí, Teresina, pp 109-119

Alves F de M (2014) Análise genética populacional de Prosopis rubriflora Hassl. ("espinheiro") e Prosopis ruscifolia Griseb. ("algaroba") (Leguminosae, Mimosoideae) em áreas de Chaco brasileiro. Universidade Estadual de Campinas

Andrade SAC, Metri JC, de Barros Neto B, Guerra NB (2003) Desidratação osmótica do jenipapo (Genipa americana L.). Ciência e Tecnol Aliment 23:276-281. https://doi.org/10.1590/ s0101-20612003000200029

Arakaki DG, dos Santos VS, de Melo EP, Pereira H, Figueiredo PS, Cortês MR, Carollo CA, de Oliveira LCS, Tschinkel P, Reis F, Souza I, Rosa R, Sanches F, dos Santos EF, do Nascimento 
VA (2020) Canjiqueira fruit: are we losing the best of it? Foods 9:1-15. https://doi.org/10.3390/ foods 9040521

Arenas P, Scarpa GF (2007) Edible wild plants of the Chorote Indians, Gran Chaco, Argentina. Bot J Linn Soc 153:73-85. https://doi.org/10.1111/j.1095-8339.2007.00576.x

Barbosa da Silva FH, Arieira J, Parolin P, Nunes da Cunha C, Junk WJ (2016) Shrub encroachment influences herbaceous communities in flooded grasslands of a neotropical savanna wetland. Appl Veg Sci 19:391-400. https://doi.org/10.1111/avsc.12230

Barbosa MM, Macedo MLR, Aiko Hiane P, Damasceno-Júnior GA, Braga Neto JA, Mendonça LABM, De Cássia Avellaneda Guimarães R, do Nascimento VA (2017) Proteins of Oryza latifolia from Brazilian Pantanal: impact on the use of aminoacids and weight gain of animals. Int J Dev Res 07:16885-16891

Bernardi C, Freyre M, Sambucetti ME, Pirovani ME (2004) Use of ascorbic and citric acids to increase dialyzable iron from vinal (Prosopis ruscifolia) pulp. Plant Foods Hum Nutr 59:175-179. https://doi.org/10.1007/s11130-004-0047-9

Bertazzoni EC, Damasceno-Júnior GA (2011) Aspectos da biologia e fenologia de Oryza latifolia Desv. (Poaceae) no Pantanal sul-mato-grossense. Acta Bot Bras 25:476-486. https://doi. org/10.1590/S0102-33062011000200023

Biazotto KR, de Souza Mesquita LM, Neves BV, Braga ARC, Tangerina MMP, Vilegas W, Mercadante AZ, De Rosso VV (2019) Biodiversity fruits: discovering bioactive compounds from underexplored sources. J Agric Food Chem 67:1860-1876. https://doi.org/10.1021/acs. jafc. $8 \mathrm{~b} 05815$

Boeri PA (2016) Bioprospección química y propagación de plantas nativas del monte patagónico como estrategias de conservación y uso sustentable. Universidad Nacional de La Plata

Borges CA, Werlw HJS, Rosa DB, Paiva DJ, Moraes EP, Silva LBSM (1997) Geomorfologia. In: BRASIL. Ministério do Meio Ambiente dos RH e da AL (ed) Plano de Conservação da Bacia do Alto Paraguai (Pantanal) - PCBAP. Diagnóstico dos meios físico e biótico. MMA/SEMAM/ PNMA, Brasília, pp 73-119

Bortolotto IM, de Mello Amorozo MC, Neto GG, Oldeland J, Damasceno-Junior GA (2015) Knowledge and use of wild edible plants in rural communities along Paraguay River, Pantanal, Brazil. J Ethnobiol Ethnomed 11. https://doi.org/10.1186/s13002-015-0026-2

Bortolotto IM, Hiane PA, Ishii IH, de Souza PR, Campos RP, Juraci Bastos Gomes R, da Silva Farias C, Leme FM, do Carmo de Oliveira Arruda R, de Lima Corrêa da Costa LB, DamascenoJunior GA (2017) A knowledge network to promote the use and valorization of wild food plants in the Pantanal and Cerrado, Brazil. Reg Environ Chang 17:1329-1341. https://doi. org/10.1007/s10113-016-1088-y

Bortolotto IM, Damasceno-Junior GA, Pott A (2018) Preliminary list of native food plants of Mato Grosso do Sul, Brazil. Iheringia - Ser Bot 73:101-116. https://doi. org/10.21826/2446-8231201873s101

Bortolotto IM, Seleme EP, de Araújo IPP, de Souza Moura S, Sartori ÂLB (2019) Conhecimento local sobre plantas alimentícias nativas no Chaco brasileiro. Oecol Aust 23:764-775

Caldeira SD, Hiane PA, Ramos MILR, Ramos Filho MM (2004) Caracterização físico-química do araçá (Psidium guineense SW.) e do tarumã (Vitex cymosa) do Estado de Mato Grosso do Sul. B Ceppa 22:145-154

Candil RFM, José de Arruda E, Arakaki AH (2007) O Cumbaru (Dipteryx alata Vog.), o desenvolvimento local e a sustentabilidade biológica no assentamento Andalucia, Nioaque/ MS. Interações (Campo Gd) 8:75-80. https://doi.org/10.1590/s1518-70122007000100008

Cano ANH, Cano ANH, Suárez ME, Suárez ME (2020) Ethnobiology of algarroba beer, the ancestral fermented beverage of the Wichí people of the Gran Chaco I: a detailed recipe and a thorough analysis of the process. J Ethn Foods 7:1-12. https://doi.org/10.1186/s42779-019-0028-0

Ciconini G, Favaro SP, Roscoe R, Miranda CHB, Tapeti CF, Miyahira MAM, Bearari L, Galvani F, Borsato AV, Colnago LA, Naka MH (2013) Biometry and oil contents of Acrocomia aculeata fruits from the Cerrados and Pantanal biomes in Mato Grosso do Sul, Brazil. Ind Crop Prod 45:208-214. https://doi.org/10.1016/j.indcrop.2012.12.008 
Coelho-Ravagnani C de F, Corgosinho FC, Sanches FLFZ, Prado CMM, Laviano A, Mota JF (2020) Dietary recommendations during the COVID-19 pandemic. Nutr Rev:1-14. https://doi. org/10.1093/nutrit/nuaa067

Damasceno-Junior GA, Souza PR, Bortolotto IM, Ramos MIL, Hiane PA, Braga Neto JA, Ishii IH, Costa DC, Ramos-Filho MM, Gomes RJB, Barbosa MM, Rodrigues RB (2010) Sabores do Cerrado \& Pantanal: Receitas e boas práticas de aproveitamento. In: Damasceno-Junior GA, Souza PR (eds). Editora UFMS, Campo Grande, p 141

Damasceno-Junior GA, Semir J, Maës Dos Santos FA, Leitão-Filho HDF (2005) Structure, distribution of species and inundation in a riparian forest of Rio Paraguai, Pantanal, Brazil. Flora 200:119-135. https://doi.org/10.1016/j.flora.2004.09.002

Damasceno-Junior GA, Bortolotto IM, Sartori ÂLB, Pott A, Souza PR (2017) Tipos de Vegetação em Mato Grosso do Sul: fontes de plantas alimentícias. UFMS, Campo Grande

Damasceno-Junior GA, da Silva RH, Gris D, de Souza EB, da Rocha M, Pineda DAM, de Amador GA, Oldeland J, Pott A (In press) Monodominant stands in the Pantanal. In: Junior GAD, Pott A (eds) Flora and vegetation of Pantanal Wetland. Springer, New York

Depenthal J, Meitzner Yoder LS (2017) Community use and knowledge of Algarrobo (Prosopis pallida) and implications for Peruvian dry forest conservation. Rev Ciencias Ambient 52:49. https://doi.org/10.15359/rca.52-1.3

Dias FRT, Galvani F (2017) Custeio e Investimento do Sistema Artesanal de Produção da Farinha de Bocaiuva. Doc 147

do Nascimento VT, de Lucena RFP, Maciel MIS, Albuquerque UP (2013) Knowledge and use of wild food plants in areas of dry seasonal forests in Brazil. Ecol Food Nutr 52:317-343 . https:// doi.org/10.1080/03670244.2012.707434

Filgueiras TS, Valls JFM, Oliveira RP (2015) Oryza. In: List. Espécies da Flora do Bras

Finco FDBA, Silva IG, de Oliveira RB (2012) Physicochemical characteristcs and antioxidant activity of three native fruits from Brazilian savannah (Cerrado). Aliment e Nutr 23:179-185

Flora do Brasil (2020) Flora do Brasil 2020 em construção. In: Jard. Botânico do Rio Janeiro. http://floradobrasil.jbrj.gov.br/. Accessed 3 Aug 2020

Freitas de Lima F, Traesel GK, Menegati SELT, dos Santos AC, Souza RIC, de Oliveira VS, Sanjinez-Argandoña EJ, Cardoso CAL, Oesterreich SA, do Carmo Vieira M (2017) Acute and subacute oral toxicity assessment of the oil extracted from Attalea phalerata Mart ex Spreng. pulp fruit in rats. Food Res Int 91:11-17. https://doi.org/10.1016/j.foodres.2016.11.019

Freyre M, Astrada E, Blasco C, Baigorria C, Rozycki V, Bernardi C (2003) Valores nutricionales de frutos de Vinal (Prosopis ruscifolia): consumo humano y animal. Cienc y Tecnol Aliment 4:41-46. https://doi.org/10.1080/11358120309487617

GBIF.org (2018) Ocorrência GBIF

Gonzalez CA (2006) Nutrition and cancer: the current epidemiological evidence. Br J Nutr 96:S42-S45. https://doi.org/10.1079/bjn20061699

Gorostegui HA, Orrabalis CJ, Guzmán CA, Calandri EL (2011) Physicochemical properties of fruit, pericarp and seeds from Copernicia alba morong, harvested in the Province of Formosa, Argentina. Nat Neotrop 42:35-43

Greiner T (2013) Vitamin A: moving the food-based approach forwad T. FAO, pp 1-69

Guevara M, Valdés-Silverio LA, Granda-Albuja MG, Iturralde G, Jaramillo-Vivanco T, Giampieri F, Santos-Buelga C, González-Paramás AM, Battino M, Álvarez-Suarez JM (2020) Pechiche (Vitex cymosa Berteo ex Speng), a nontraditional fruit from Ecuador, is a dietary source of phenolic acids and nutrient minerals, in addition to efficiently counteracting the oxidative-induced damage in human dermal fibroblasts. Antioxidants 9. https://doi.org/10.3390/antiox9020109

Hamacek FR, Moreira AVB, Martino HSD, Ribeiro SMR, Pinheiro-Sant'Ana HM (2013) Valor nutricional, caracterização Física e físico-química de jenipapo (Genipa Americana L.) do cerrado de Minas Gerais. Aliment e Nutr 24:73-77

Hartmann T (1967) Nomenclatura Botânica dos Borôro (Materiais para um ensaio etno-botânico). São Paulo 
Hart TB (1990) Monospecific dominance in tropical rain forests. Trends Ecol Evol 5:6-11. https:// doi.org/10.1016/0169-5347(90)90005-X

Herberts AL (1998) OS Mbayá-Guaikurú: área, assentamento, subsistência e cultura material. Universidade Vale do rio dos Sinos

Hiane PA, Ramos MM, Ramos MIL, Macedo MLR (2005) Óleo da polpa e amêndoa de bocaiúva, Acrocomia aculeata (Jacq.) Lodd. Caracterização e composição em ácido graxos. Braz J Food Technol 8:256-259

Hiane PA, Baldasso PA, Marangoni S, Macedo MLR (2006) Chemical and nutritional evaluation of kernels of bocaiuva. Ciência e Tecnol Aliment Campinas 26:683-689. https://doi.org/10.1590/ S0101-20612006000300031

Hiane PA, Ramos Filho MM, Ramos MILR, Braga Neto JA, Barbosa MM, Costa DC (2010) Frutos nativos do Cerrado e Pantanal, Qualidade nutricional e sabor peculiar (ainda) pouco aproveitados. In: Damasceno-Junior GA, de Souza PR (eds) Sabores do Cerrado e Pantanal: receitas e boas práticas de aproveitamento. UFMS, Campo Grande, pp 131-136

IBGE (2010) Censo demográfico 2010. https://censo2010.ibge.gov.br. Accessed 31 July 2020

Kinupp VF, Lorenzzi H (2014) Plantas Alimentícias Não Convencionais (PANC) no Brasil. Instituto Plantarum de Estudos da Flora, Nova Odessa

Lima MC de, Portari GV (2019) Centesimal composition and antioxidant compounds of two fruits from the Cerrado (Brazilian Savannah). Rev Ceres 66:41-44. https://doi. org/10.1590/0034-737X201966010006

Lima AJB de, Corrêa AD, Alves APC, Abreu CMP, Dantas-Barros AM (2008) Caracterização química do fruto jabuticaba (Myrciaria cauliflora Berg) e de suas frações. Arch Latinoam Nutr $58: 416-421$

Lima FF de, Menegati SELT, Traesel GK, Araújo FHS de, Lescano CH, Peixoto SM, Mao Silva FA, Vieira SCH, Vieira MDC, Oesterreich SA (2016) Study on the cytotoxic, genotoxic and clastogenic potential of Attalea phalerata Mart. Ex Spreng. Oil pulp in vitro and in vivo experimental models. PLoS One 11:1-12. https://doi.org/10.1371/journal.pone.0165258

Lima FF de, Lescano CH, Arrigo JS, Cardoso CAL, Coutinho JP, Bonfá Moslaves IS, Ximenes TV do N, Toffoli Kadri MC, Weber SS, Perdomo RT, Leite Kassuya CA, Vieira MC, Sanjinez-Argandoña EJ (2018) Anti-inflammatory, antiproliferative and cytoprotective potential of the Attalea phalerata Mart. ex Spreng. pulp oil. PLoS One 13:1-17. https://doi. org/10.1371/journal.pone.0195678

Lima DB, Damiani LP, Fujimori E (2018) Deficiência de Vitamina A em crianças brasileiras e variáveis associadas. Rev Paul Pediatr 36:176-185. https://doi. org/10.1590/1984-0462/;2018;36;2;00013

Lorenzi H (2010) Flora brasileira Lorenzi: Arecaceae. Instituto Plantarum, Nova Odessa

Lulekal E, Asfaw Z, Kelbessa E, Van Damme P (2011) Wild edible plants in Ethiopia: a review on their potential to combat food insecurity. Afr Focus 24:71-121. https://doi.org/10.21825/ af.v24i2.4998

Mamone G, Sciammaro L, De Caro S, Di Stasio L, Siano F, Picariello G, Puppo MC (2019) Comparative analysis of protein composition and digestibility of Ceratonia siliqua L. and Prosopis spp. seed germ flour. Food Res Int 120:188-195. https://doi.org/10.1016/j. foodres.2019.02.035

Marcelino G, Donadon JR, Caires ARL, Michels FS, Oliveira LCS, Cortes MR, Maldonade IR, Cavalheiro LF, Nazário CED, Maróstica Júnior MR, Santos NMD, Batista PB, Pott A, Nunes ÂA, Figueiredo PS, Hiane PA, Nascimento VA, Guimarães RCA (2018) Characterization and oxidative stability of oils and bioactive compounds of the fruits of Byrsonima cydoniifolia A. Juss. at different ripening stages. J Sci Food Agric 99:2855-2864. https://doi.org/10.1002/ jsfa.9498

Marimon BS, de Souza Lima E (2001) Caracterização fitofisionômica e levantamento florístico preliminar no Pantanal dos Rios Mortes-Araguaia, Cocalinho, Mato Grosso, Brasil. Acta Bot Bras 15:213-229. https://doi.org/10.1590/S0102-33062001000200008 
Marin AMF (2006) Potencial nutritivo de frutos do Cerrado: composição em minerais e componentes não convencionais. Universidade de Brasília

Martins RC, Filgueiras TDS, Albuquerque UP (2014) Use and diversity of palm (Arecaceae) resources in central Western Brazil. Sci World J 2014. https://doi.org/10.1155/2014/942043

May P, da Vinha VV (2013) Investing in sustainable use of biodiversity for social benefit in Brazil. In: Muradian R, Rival L (eds) Governing the provision of ecosystem services. Springer, pp. $21-47$

Mendes M, de Almeida Silva M, da Silva Neves SM, Neves R, Junior SS (2014) A organização e a produção agroindustrial extrativista na fronteira Brasil-Bolívia, na região sudoeste de Mato Grosso. Rev Conex UEPG 10:140-149

Mendoza V, Santos L, Sanjinez-Argadoña E (2016) Elaboração de granola com adição de polpa e castanha de bacuri para consumo com iogurte. Evidência, Joaçaba 16:83-100. https://doi. org/10.18593/eba.v16i2.10382 ARTIGO

Menendez-Baceta G, Aceituno-Mata L, Tardío J, Reyes-García V, Pardo-de-Santayana M (2012) Wild edible plants traditionally gathered in Gorbeialdea (Biscay, Basque Country). Genet Resour Crop Evol 59:1329-1347. https://doi.org/10.1007/s10722-011-9760-z

MMA (2016) Espécies nativas da flora brasileira de valor econômico atual ou potencial : plantas para o futuro : região Centro-Oeste. Brasília

Molina M, Pardo-de-Santayana M, García E, Aceituno-Mata L, Morales R, Tardío J (2012) Exploring the potential of wild food resources in the Mediterranean region: natural yield and gathering pressure of the wild asparagus (Asparagus acutifolius L.). Spanish. J Agric Res 10:1090. https://doi.org/10.5424/sjar/2012104-3050

Moraes RM (2014) Palmeras útiles de Bolivia. Editores, Herbario Nacional de Bolibia/ Plural, La Paz

Moraes RM, Borchsenius F, Blicher-Mathiesen U (1996) Notes on the biology and uses of the motacú palm (Attalea phalerata, Arecaceae) from Bolivia. Econ Bot 50:423-428. https://doi. org/10.1007/BF02866525

Nesbitt M, McBurney RPH, Broin M, Beentje HJ (2010) Linking biodiversity, food and nutrition: the importance of plant identification and nomenclature. J Food Compos Anal 23:486-498. https://doi.org/10.1016/j.jfca.2009.03.001

Noguchi DK, Nunes GP, Sartori ÂLB (2009) Florística e síndromes de dispersão de espécies arbóreas em remanescentes de Chaco de Porto Murtinho, Mato Grosso do Sul, Brasil. Rodriguésia 60:353-365. https://doi.org/10.1590/2175-7860200960208

Nogueira LMS, Figueiredo PS, Miyagusku L, Campos RP, Hiane PA, de Cássia Avellaneda Guimarães R, Aréco AET (2018) Characterization and sensorial acceptance of frozen yogurt formulated with Laranjinha de pacu (Pouteira glomerata (Miq.) Radlk) and probiotic cultures. Ambiência 14:174-185. https://doi.org/10.5935/ambiencia.2018.12.01

Nyström M, Jouffray JB, Norström AV, Crona B, Søgaard Jørgensen P, Carpenter SR, Bodin O, Galaz V, Folke C (2019) Anatomy and resilience of the global production ecosystem. Nature 575:98-108. https://doi.org/10.1038/s41586-019-1712-3

Oberg K (1949) Terena and the Caduveo of Southern Mato Grosso, Brazil. United States Government Printing Office, Washington

Oliveira CE da S, Zuffo AM, Fonseca WL, Steiner F (2019) Physical characterization of fruits and seeds Inga laurina (Sw.) Willd. (Fabaceae - Mimosaceae). J Neotrop Agric 6:105-111. https:// doi.org/10.32404/rean.v6i3.3006

Oliveira JE (1996) Guató - Argonautas do Pantanal. Porto Alegre

Pacheco P, da Paz JG, da Silva CO, Pascoal GB (2014) Centesimal composition, bioactive compounds, physicochemical parameters in in natura jenipapo (Genipa americana L.). Demetra 9:1041-1054. https://doi.org/10.12957/demetra.2014.11310

Pardo de Santayana M, Morales R, Aceituno L, Molina M, Tardío J (2012) Etnobiología y biodiversidad: el Inventario Español de los Conocimientos Tradicionales. Ambienta 99:6-24

Peña R (1976) Flora Cruceña. Litografia y Imprentas Unidas, La Paz 
Peña-Chocarro M, De Egea J, Vera M, Maturo H, Knapp S (2006) Guía de árboles y arbustos del Chaco Húmedo. The Natural History Museum, Guyra Paraguay, Fundación Moisés Bertoni, y Fundación Hábitat y Desarrollo, Asunción

Pennington TD (1997) The genus Inga botany. The Royal Botanic Gardens, Kew, London

Pereira RJ, Cardoso MDG (2012) Metabólitos secundários vegetais e benefícios antioxidantes vegetable secondary metabolites and antioxidants benefits. J Biotechnol Biodivers 3:146-152

Pinela J, Carvalho AM, Ferreira ICFR (2017) Wild edible plants: nutritional and toxicological characteristics, retrieval strategies and importance for today's society. Food Chem Toxicol 110:165-188. https://doi.org/10.1016/j.fct.2017.10.020

Pott A, Pott VJ (1986) Plantas comestíveis e medicinais da Nhecolândia. Pantanal, Corumbá

Pott A, Pott VJ (1994) Plantas do Pantanal. Embrapa, Corumbá

Pott VJ, Pott A (2000) Plantas Aquáticas do Pantanal. Embrapa. Centro de Pesquisa Agropecuária do Pantanal, Corumbá

Pott A, Pott VJ (In press) Flora of the Pantanal. In: Damasceno-Junior GA, Pott A (eds) Flora and vegetation of Pantanal Wetland. Springer, New York

Pott A, Pott VJ, Sobrinho AAB (2004) Plantas úteis à sobrevivência no Pantanal. IV Simpósio sobre Recur Nat e Sócio-econômico do Pantanal, pp 1-16

Prado DE, Gibbs P, Pott A, Pott VJ (1992) The Chaco - Pantanal transition in southern Mato Grosso, Brazil. In: Furley P, Proctor J (eds) Nature and dynamics of forest savanna boundaries, Chapman \& Hill, London, pp 451-470

Prance GT(1989) Manual de Botânica Econômica, 253 p

Prance GT, Schaller GB (1982) Preliminary study of some vegetation types of the Pantanal, Mato Grosso, Brazil. Brittonia 34:228-251. https://doi.org/10.2307/2806383

Prates MFO, Campos RP, da Silva MMB, Macedo MLR, Hiane PA, Ramos Filho MM (2015) Nutritional and antioxidant potential of canjiqueira fruits affected by maturity stage and thermal processing. Ciência Rural 45:399-404. https://doi.org/10.1590/0103-8478cr20131272

Ramos MIL, Siqueira EMA, Isomura CC, Barbosa AMJ, Arruda SF (2007) Bocaiuva (Acrocomia aculeata (Jacq.) Lodd) improved vitamin A status in rats. J Agric Food Chem 55:3186-3190. https://doi.org/10.1021/jf063305r

Ramos MIL, Ramos Filho MM, Hiane PA, Braga Neto JA, de Almeida Siqueira EM (2008) Qualidade nutricional da polpa de bocaiúva Acrocomia aculeata (Jacq.) Lodd. Cienc e Tecnol Aliment 28:90-94. https://doi.org/10.1590/s0101-20612008000500015

Ramos M de LM, Rodrigues G da CG, Soares WRG, Hiane PA, Ramos MIL, Almeida JA de, Sanches FLFZ (2017) Suplementação com amêndoa de bacuri na composição corporal de ratos submetidos ao exercício. Rev Bras Med do Esporte 23:294-299

Siqueira EMA, Rosa FR, Fustinoni AM, de Sant'Ana LP, Arruda SF (2013) Brazilian savanna fruits contain higher bioactive compounds content and higher antioxidant activity relative to the conventional red delicious apple. PLoS One 8:2-8. https://doi.org/10.1371/journal.pone.0072826

Souza-Lima ES, Sinani TR, Pott A, Sartori ÂLB (2017) Mimosoideae (Leguminosae) in the Brazilian Chaco of Porto Murtinho, Mato Grosso do Sul. Rodriguesia 68:263-290. https://doi. org/10.1590/2175-7860201768131

Santos VS dos, Nascimento TV, Felipe JL, Boaretto AG, Damasceno-Junior GA, Silva DB, Toffoli-Kadri MC, Carollo CA (2017) Nutraceutical potential of Byrsonima cydoniifolia fruits based on chemical composition, anti-inflammatory, and antihyperalgesic activities. Food Chem 237:240-246. https://doi.org/10.1016/j.foodchem.2017.05.082

Salis SM, Mattos PP (2009) Floração e Frutificação da Bocaiúva (Acrocomia aculeata) e do Carandá no Pantanal. Comun técnico - EMBRAPA, pp 1-6

Sanjinez-Argandoña EJ, Chuba CAM (2011) Biometrical, physical and chemical characterization of bocaiuva (Acrocomia aculeata (Jacq.) lodd. ex mart) palm fruits. Rev Bras Frutic 33:1023-1028. https://doi.org/10.1590/S0100-29452011000300040

Santos K FD'eN, Silveira s, Martin-Didonet CCG, Brondani C (2013) Storage protein profile and amino acid content in wild rice oryza glumaepatula. Pesqui Agropecu Bras 48:66-72. https:// doi.org/10.1590/S0100-204X2013000100009 
Sartori ALB, Pott VJ, Pott A, De Carvalho FS (2018) Checklist of angiosperm from the Chaco of Mato Grosso do Sul. Iheringia - Ser Bot 73:22-33. https://doi. org/10.21826/2446-8231201873s22

Schmeda-Hirschmann G (1994) Plant resources used by the Ayoreo of the Paraguayan Chaco. Econ Bot 48:252-258. https://doi.org/10.1007/BF02862325

Schmidt M (1942) Estudos de Etnologia Brasileira. Nacional, Companhia Editorra, São Paulo

Schulz DG, Oro P, Volkweis C, de Matos Malavasi M, Malavasi UC (2014) Physiological maturity and morphometry of Inga laurina (Sw.) willd. seeds. Floresta e Ambient 21:45-51. https://doi. org/10.4322/floram.2014.007

Silva RH (2018) Estabelecimento de protocolo para uso sustentável de Copernicia alba Morong ex Morong \& Briton. Universidade Federal de Mato grosso do Sul

Silva MLC, Costa RS, Dos Santos Santana A, Koblitz MGB (2010) Phenolic compounds, carotenoids and antioxidant activity in plant products. Semin Agrar 31:669-682. https://doi. org/10.5433/1679-0359.2010v31n3p669

Silva VM da, Campos RP, Borsato AV, Candido CJ, Donadon JR (2017) Bocaiuva jelly: preparation, physicochemical and sensory evaluation/Geleia de bocaiuva: elaboracao, avaliacao fisico-quimica e sensorial. Rev Bras Frutic 40. http://dx.doi-org.ez51.periodicos.capes.gov. br/10.1590/0100-29452018846 Resumo

Silva Baldivia D da, Sanjinez-Argandonã EJ, Antunes KÁ, Moraes ICF, Dos Santos EL, De Picoli Souza K (2018) The chemical composition and metabolic effects of Attalea phalerata nut oil in hyperlipidemic rats induced by a high-fructose diet. Molecules 23. https://doi.org/10.3390/ molecules 23040960

Silva Filho OJ da, Gomes Júnior NN (2020) O amanhã vai à mesa: abastecimento alimentar e COVID-19. Cad Saude Publica 36:e00095220. https://doi.org/10.1590/0102-311x00095220

Siqueira I, Pelegrin J, Candido C, Santos E, RCA Guimarães, Sanches F (2016) Composição nutricional do bacuri (Scheelea phalerata Mart.) e efeitos de diferentes processos de extração da polpa. In: XXV Congresso Brasileiro de Ciência e Tecnologia de Alimentos

Smith E, Ahmed S, Dupuis V, Running Crane M, Eggers M, Pierre M, Flagg K, Byker Shanks C (2019) Contribution of wild foods to diet, food security, and cultural values amidst climate change. J Agric Food Syst Community Dev 9:1-24. https://doi.org/10.5304/jafscd.2019.09b.011

Teixeira BS, Suzuki RM, Tonin LTD (2020) Capacidade antioxidantes e compostos bioativos dos frutos de Pouteria glomerata (laranjinha-de-pacu). Rev Tecnológica 29:291-308. https://doi. org/10.4025/revtecnol.v29i2.50511

Termote C, Van Damme P, Djailo B D'a (2011) Eating from the wild: Turumbu, Mbole and Bali traditional knowledge on non-cultivated edible plants, District Tshopo, DRCongo. Genet Resour Crop Evol 58:585-618. https://doi.org/10.1007/s10722-010-9602-4

Tomas WM, de Oliveira Roque F, Morato RG, Medici PE, Chiaravalloti RM, Tortato FR, Penha JMF, Izzo TJ, Garcia LC, Lourival RFF, Girard P, Albuquerque NR, Almeida-Gomes M, da Silva Andrade MH, Araujo FAS, Araujo AC, de Arruda EC, Assunção VA, Battirola LD, Benites M, Bolzan FP, Boock JC, Bortolotto IM, da Silva Brasil M, Camilo AR, Campos Z, Carniello MA, Catella AC, Cheida CC, Crawshaw PG, Crispim SMA, Junior GAD, Desbiez ALJ, Dias FA, Eaton DP, Faggioni GP, Farinaccio MA, Fernandes JFA, Ferreira VL, Fischer EA, Fragoso CE, Freitas GO, Galvani F, Garcia AS, Garcia CM, Graciolli G, Guariento RD, Guedes NMR, Guerra A, Herrera HM, Hoogesteijn R, Ikeda SC, Juliano RS, Kantek DLZK, Keuroghlian A, Lacerda ACR, Lacerda ALR, Landeiro VL, Laps RR, Layme V, Leimgruber P, Rocha FL, Mamede S, Marques DKS, Marques MI, Mateus LAF, Moraes RN, Moreira TA, Mourão GM, Nicola RD, Nogueira DG, Nunes AP, da Nunes da Cunha C, Oliveira MD, Oliveira MR, Paggi GM, Pellegrin AO, Pereira GMF, Peres IAHFS, Pinho JB, Pinto JOP, Pott A, Provete DB, dos Reis VDA, dos Reis LK, Renaud PC, Ribeiro DB, Rossetto OC, Sabino J, Rumiz D, Salis SM, Santana DJ, Santos SA, Sartori ÂL, Sato M, Schuchmann KL, ScreminDias E, Seixas GHF, Severo-Neto F, Sigrist MR, Silva A, Silva CJ, Siqueira AL, Soriano BMA, Sousa LM, Souza FL, Strussmann C, Sugai LSM, Tocantins N, Urbanetz C, Valente-Neto F, Viana DP, Yanosky A, Junk WJ (2019) Sustainability agenda for the Pantanal Wetland: perspec- 
tives on a collaborative Interface for science, policy, and decision-making. Trop Conserv Sci 12. https://doi.org/10.1177/1940082919872634

UNICAMP (2011) Tabela brasileira de composição nutricional de alimentos - TACO, 4th edn. NEPA - UNICAMP, Campinas

Valko M, Rhodes CJ, Moncol J, Izakovic M, Manzur M (2006) Free radicals, metals and antioxidants in oxidative stress-induced câncer. Chemico-Biol Interact 160(1):1-40

Veiga Dias V da, Schultz G, Schuster M da S, Talamini E, Révillion JP (2015) The organic food market: a quantitative and qualitative overview of international publications. Ambient Soc 18:155-174. https://doi.org/10.1590/1809-4422ASOC841V1812015en

Vianna SA, Campos-Rocha A (2020) Acrocomia in Flora do Brasil 2020 em construção

Wittman H (2012) Food sovereignty: a new rights framework for food and nature? Environ Soc 2. https://doi.org/10.3167/ares.2011.020106 